\title{
PENGARUH MOTIVASI KERJA TERHADAP KEPUASAN KERJA PEGAWAI LEMBAGA PEMBINAAN KHUSUS ANAK (LPKA) KLAS IIA AMBON DALAM PERSPEKTIF KRISTIANI
}

\author{
Imelda Ch. Poceratu \\ E-mail: Imelda.poceratu@yahoo.com \\ Dosen Fakultas Teknik Unpatti
}

\begin{abstract}
ABSTRAK
Motivasi kerja dapat didefinisikan sebagai suatu dorongan secara psikologis kepada seseorang yang menentukan arah dari perilaku (direction of behavior) seseorang dalam organisasi, tingkat usaha (level of effort), dan tingkat kegigihan atau ketahanan di dalam menghadapi suatu halangan atau masalah (level of persistence). Jadi motivasi kerja dapat diartikan sebagai semangat kerja yang ada pada karyawan yang membuat karyawan tersebut dapat bekerja untuk mencapai tujuan tertentu. Sesuai dengan tingkatan motivasi manusia yang dikemukakan maka upah atau gaji termasuk pada kebutuhan dasar. Good Watson memberikan komentar : bahwasannya dengan memberikan gaji yang cukup tinggi belum tentu menjamin adanya kepuasan kerja bagi karyawan. Jadi gaji atau upah bukanlah satu-satunya faktor yang dapat menimbulkan kepuasan bagi seseorang.

Dalam perspektif kristiani kerja adalah suatu fakta alkitabiah bahwa kata 'kerja' pertama kali muncul dikenakan pada identitas Allah, pada diri Allah dan bukan diri manusia (Kejadian. 2:2: "Ketika Allah pada hari ketujuh telah menyelesaikan pekerjaan yang dibuat-Nya itu, berhentilah Ia pada hari ketujuh dari segala pekerjaan yang telah dibuatNya itu"). Dengan kata lain, kerja adalah salah satu hakekat Allah. Ketika manusia bekerja, sesungguhnya itu adalah bagian dari gambar dan rupa Allah yang ia miliki (Kejadian 1:26, 27). Binatang dan mahluk-mahluk lain tidak bekerja. Kerja bukanlah kutukan Taman Eden. Dengan demikian, ketika kita bekerja, kita menjalankan hakekat kita sebagai manusia. Hakekat manusia yang merupakan turunan dari hakekat Allah. Manusia yang tidak bekerja telah kehilangan hakekatnya sebagai manusia. Manusia yang lebih menyukai bermalas-malasan juga telah kehilangan hakekatnya sebagai manusia. Dengan demikian, kerja yang adalah hakekat yang diberikan Allah kepada manusia hendaknya menjadi motivasi kerja kepada setiap umat-Nya.
\end{abstract}

Kata Kunci: Motivasi kerja, kepuasan kerja,Kerja adalah Ibadah.

\section{PENDAHULUAN}

Kerja merupakan sesuatu yang dikeluarkan oleh seseorang sebagai profesi, sengaja dilakukan untuk mendapatkan penghasilan. Kerja dapat juga di artikan sebagai pengeluaran energi untuk kegiatan yang dibutuhkan oleh seseorang untuk mencapai tujuan tertentu. Dari pernyataan tersebut dapat dikatakan bahwa pekerjaan memungkinkan orang untuk dapat menyatakan diri secara objektif kedunia ini, sehingga ia dan orang lain dapat memandang dan memahami kebenaran dirinya. Dimensi kerja kedua adalah dimensi psikologis. Dalam arti ini kerja bisa berarti berkat sekaligus kutuk. Orang perlu untuk bekerja. Sejak dulu manusia sudah memiliki pandangan, bahwa kerja adalah sesuatu yang suci. Kerja adalah suatu bentuk panggilan dari Tuhan. Kerja adalah suatu pengabdian, apapun bentuknya, dan semua itu layak mendapatkan penghormatan. Motivasi merupakan suatu proses yang dimulai dengan adanya kekurangan psikologis atau kebutuhan yang menimbulkan suatu dorongan dengan maksud mencapai suatu tujuan atau insentif. Pengertian proses motivasi ini dapat dipahami melalui hubungan antara kebutuhan, dorongan dan insentif (tujuan). Motivasi dalam dunia kerja adalah suatu yang dapat menimbulkan semangat atau dorongan kerja. Motivasi kerja juga berpengaruh pada kepuasan kerja pegawai LPKA Klas IIA Ambon. Secara iman Kristen kerja merupakan salah satu Hakekat Allah, maka manusia haruslah menjadikan ini sebagai dasar atau motivasi dalam bekerja.

\section{KAJIAN TEORI DAN METODE}

\section{II.1. Kajian Teori}

motivasi adalah suatu kumpulan kekuatan energik yang mengkoordinasi di dalam 
dan di luar diri seorang pekerja, yang mendorong usaha kerja dalam menentukan arah perilaku, tingkat usaha, intensitas, dan kegigihan. Motivasi kerja dapat didefinisikan sebagai suatu dorongan secara psikologis kepada seseorang yang menentukan arah dari perilaku (direction of behavior) seseorang dalam organisasi, tingkat usaha (level of effort), dan tingkat kegigihan atau ketahanan di dalam menghadapi suatu halangan atau masalah (level of persistence). Jadi motivasi kerja dapat diartikan sebagai semangat kerja yang ada pada karyawan yang membuat karyawan tersebut dapat bekerja untuk mencapai tujuan tertentu (George and Jones, 2005).

Motif seringkali diartikan dengan istilah dorongan. Dorongan atau tenaga tersebut merupakan gerakan jiwa dan jasmani untuk berbuat. Sehingga motif tersebut merupakan suatu driving force yang menggerakan manusia untuk bertingkah laku dan dalam perbuatannya itu mempunyai tujuan tertentu. Pengertian motivasi yang dikemukakan oleh Wexley dan Yulk adalah pemberian atau penimbulan motif. Jadi motivasi kerja adalah sesuatu yang menimbulkan semangat atau dorongan kerja. Oleh sebab itu motivasi kerja dalam psikologi karya biasa disebut pendorong semangat kerja. Kuat dan lemahnya motivasi kerja ikut menentukan besar kecilnya prestasinya.

\section{Hakekat Kerja}

Dalam kehidupan manusia selalu mengadakan bermacam-macam aktivitas. Salah satu aktivitas itu diujudkan dalam gerakan gerakan yang dinamakan kerja. Bekerja mengandung arti melaksanakan suatu tugas yang diakhiri dengan buah karya yang dapat dinikmati oleh manusia yang bersangkutan. Menurut Mc. Gregor, seorang itu bekerja karena bekerja itu merupakan kondisi bawaan seperti bermain atau beristirahat, untuk aktif dan mengerjakan sesuatu. Kemudian Smith dan Wakeley, menambahkan dengan teorinya yang menyatakan bahwa seseorang didorong untuk beraktivitas karena dia berharap bahwa hal ini akan membawa pada keadaan yang lebih memuaskan daripada keadaan sekarang.

Faktor pendorong penting yang menyebabkan manusia bekerja adalah adanya kebutuhan yang harus dipenuhi. Aktivitas dalam kerja mengandung unsur suatu kegiatan sosial, menghasilkan sesuatu, dan pada akhirnya bertujuan untuk memenuhi kebutuhannya. Namun demikian dibalik dari tujuan yang tidak langsung tersebut orang bekerja juga untuk mendapatkan imbalan hasil kerja yang akan menggantungkan hidupnya kepada perusahaan dengan menerima upah atau gaji dari hasil kerjanya itu. Jadi pada hakekatnya orang bekerja tidak saja untuk mempertahankan kelangsungan hidupnya, tetapi juga bertujuan untuk mencapai taraf hidup yang lebih baik.

Jadi bekerja adalah suatu bentuk yang bertujuan untuk mendapatkan kepuasan. Dan aktivitas ini melibatkan baik fungsi fisik maupun mental. Pendapat dari Gilmer (1971), bahwa bekerja itu merupakan proses fisik maupun mental manusia dalam mencapai tujuannya. Dari sini dapat disimpulkan bahwa bekerja adalah aktivitas manusia baik fisik maupun mental yang dasarnya adalah bawaan dan mempunyai tujuan yaitu mendapat kepuasan. Ini tidak berarti bahwa semua aktivitas itu adalah bekerja, hal ini tergantung pada motivasi yang mendasari dilakukannya aktivitas tersebut.

\section{Kerja Dalam Perspektif Kristen.}

Saat ini, 'kerja' yang hendak dibahas adalah 'kerja' sebagai sebuah profesi untuk mencari nafkah. Tetapi sebelumnya, menurut Galatia 6:4: "Baiklah tiap-tiap orang menguji pekerjaannya sendiri; maka ia boleh bermegah melihat keadaannya sendiri dan bukan melihat keadaan orang lain". Dalam Galatia, pekerjaan merupakan terjemahan dari bahasa Yunani yaitu kata "ergo" yang berarti: 1. bisnis, usaha, yang dilakukan seseorang 2. suatu produk apapun yang dikerjakan oleh tangan, seni, industri atau pikiran. 3. suatu tindakan atau perbuatan atau sesuatu yang dilakukan

Walaupun arti harafiah ergo adalah pekerjaan profesi, namun Paulus menempatkannya dalam konteks iman seseorang dalam hubungannya dengan orang-orang lain. Adalah suatu fakta alkitabiah bahwa kata 'kerja' pertama kali muncul dikenakan pada identitas Allah, pada diri Allah dan bukan diri manusia (Kejadian. 2:2: "Ketika Allah pada hari ketujuh telah menyelesaikan pekerjaan yang dibuat-Nya itu, berhentilah Ia pada hari ketujuh dari segala pekerjaan yang telah dibuat-Nya itu"). Dengan kata lain, kerja adalah salah satu hakekat Allah. Ketika manusia bekerja, sesungguhnya itu adalah 
bagian dari gambar dan rupa Allah yang ia miliki (Kejadian 1:26,27). Binatang dan mahluk-mahluk lain tidak bekerja. Kerja bukanlah kutukan Taman Eden. Dengan demikian, ketika kita bekerja, kita menjalankan hakekat kita sebagai manusia. Hakekat manusia yang merupakan turunan dari hakekat Allah. Manusia yang tidak bekerja telah kehilangan hakekatnya sebagai manusia. Manusia yang lebih menyukai bermalas-malasan juga telah kehilangan hakekatnya sebagai manusia. Kerja, ergo, yang dibicarakan Alkitab tidaklah sebatas kerja di kantor. Bekerja di kantor atau perusahaan tempat seseorang bekerja adalah bagian dari 'kerja' atau ergo itu sendiri. Ketika Alkitab berbicara mengenai 'kerja', maka itu adalah keseluruhan kehidupan kita yang juga merupakan ibadah kita.

\section{Kepuasan Kerja}

Robbins \& Judge (2011) mendefinisikan kepuasan kerja sebagai perasaan positif pada suatu pekerjaan, yang merupakan dampak atau hasil evaluasi dari berbagai aspek pekerjaan tersebut. Kepuasan kerja merupakan penilaian dan sikap seseorang atau karyawan terhadap pekerjaannya dan berhubungan dengan lingkungan kerja, jenis pekerjaan, hubungan antar teman kerja, dan hubungan sosial di tempat kerja. Secara sederhana kepuasan kerja atau job satisfaction dapat disimpulkan sebagai apa yang membuat seseorang menyenangi pekerjaan yang dilakukan karena mereka merasa senang dalam melakukan pekerjaannya. Banyak orang berpendapat bahwa gaji atau upah merupakan faktor utama untuk timbulnya kepuasan kerja. Sampai taraf tertentu hal ini bisa diterima, terutama dalam suatu negarayang sedang berkembang di mana uang merupakan kebutuhan yang vital untuk bisa memenuhi kebutuhan pokok sehari-hari. Akan tetapi kalau masyarakat yang dapat memenuhi kebutuhan keluarganya secara wajar maka gaji atau upah ini tidak atau bukan faktor yang utama. Sesuai dengan tingkatan motivasi manusia yang dikemukakan maka upah atau gaji termasuk pada kebutuhan dasar.

Good Watson memberikan komentar : bahwasannya dengan memberikan gaji yang cukup tinggi belum tentu menjamin adanya kepuasan kerja bagi karyawan. Jadi gaji atau upah bukanlah satu-satunya faktor yang dapat menimbulkan kepuasan bagi seseorang. Harold E. Burt mengemukakan pendapatnya tentang faktor- faktor yang dapat menimbulkan kepuasan kerja, yaitu :

1. faktor hubungan antar karyawan, antara lain :

- hubungan antara manager dengan karyawan

- faktor fisis dan kondisi kerja

- hubungan sosial di antara karyawan

- sugesti dari teman sekerja

- emosi dan situasi kerja

2. Faktor individu, yaitu yang berhubungan dengan :

- sikap orang terhadap pekerjaanya

- umur orang sewaktu bekerja

- jenis kelamin

3. Faktor-faktor luar, yang berhubungan dengan :

- keadaan keluarga karyawan

- rekreasi

- pendidikan

\section{II.2. Metode}

Agar proses penelitian dapat berjalan dengan baik dan terarah, maka metode pengumpulan data yang digunakan dalam melakukan penelitian berupa:

1. Observasi, yaitu pengamatan secara langsung pada lokasi penelitian terhadap perilaku kerja pegawai LPKA Klas IIA Ambon.

2. Wawancara,yaitu proses Tanya jawab secara langsung dengan pihak terkait (pimpinan dan pegawai LPKA) untuk mengumpulkan data-data yang berhubungan dengan motivasi dan kepuasan kerja.

3. Studi Literatur, yaitu aktivitas penelusuran berdasarkan teori-teori (buku teks, jurnal, skripsi) yang berkaitan dengan pengaruh motivasi kerja terhadap kinerja. Tujuannya untuk mencari pendekatan yang sesuai untuk penelitian ini sekaligus melakukan perbandingan dengan penelitian-penelitian sejenis.

Untuk mengarahkan proses pengumpulan data, maka penelitian ini telah dikembangkan beberapa alat ukur berupa pertanyaan-pertanyaan (Kuisioner) yang mengukur tingkat motivasi kerja terhadap kepuasan kerja. Sedangkan metode yang digunakan untuk menganalisa data adalah: 
1. Uji Validitas, untuk memvalidasi data kuisioner tingkat motivasi dan tingkat kepuasan kerja.

2. Uji Relibialitas, untuk menguji tingkat kelayakan data kuisioner tingkat motivasi dan tingkat kepuasan.

\section{HASIL DAN PEMBAHASAN}

Lembaga Pembinaan Khusus Anak biasa disingkat dengan LPKA merupakan inovasi terbaru dari Lembaga Pemasyarakatan sebagai tempat pembinaan khusus untuk anak-anak yang terlibat kenakalan anak yang berujung dengan tindak pidana. Data pegawai LPKA Klas II Ambon berjumlah 18 orang. Kuesioner sebagai langkah awal untuk mengetahui pengaruh motivasi terhadap kepuasan kerja dibagikan kepada responden. Uji validitas dan reliabilitas kuisioner diperlukan untuk memastikan bahwa kuisioner yang digunakan dalam penelitian mampu mengukur variabel penelitian dengan baik.

Dari hasil uji validitas dan reliabelitas, maka diketahui bahwa nilai alpha adalah 0.736. Apabila dibandingkan dengan nilai $\mathrm{r}$ tabel dengan nilai $\mathrm{n}=$ 18 dengan $\mathrm{df}=\mathrm{n}-2$ atau $\mathrm{df}=18-2=16$ dengan tingkat signifikan 5\% maka diperoleh nilai tabel adalah 0.468. Sehingga dapat disimpulkan bahwa Alpha $>r$ tabel atau $0.736>0.468$. Maka dapat dikatakan bahwa masing-masing pertanyaan dapat dianggap reliabel. Hasil pengujuan validitas dan pengujian reliabelitas menunjukkan bahwa data kuesioner semua bersifat valid, sehingga dapat digunakan sebagai acuan dalam penelitian ini.

\section{HASIL DAN PEMBAHASAN}

Hasil pengujian validitas dan pengujian reliabelitas menunjukkan bahwa data kuesioner semua bersifat valid, sehingga dapat digunakan sebagai acuan dalam penelitian ini. Dari hasil diatas, dilihat bahwa motivasi kerja sangat berpengaruh terhadap kepuasan kerja para pengawai LPKA Klas IIA Ambon. Kepuasan kerja karyawan pada dasarnya sangat individualis dan merupakan hal yang sangat tergantung pada pribadi masing-masing pegawai. Namun demikian terdapat beberapa faktor yang berhubungan dengan kepuasan kerja pegawai dalam rangka peningkatan kinerja adalah: (a) faktor pekerjaan itu sendiri, merupakan faktor yang berhubungan dengan tingkat dimana pekerjaan menyediakan tugas yang menyenangkan, kesempatan belajar dan kesempatan untuk mendapatkan tanggung jawab. (b) faktor gaji, merupakan faktor yang berhubungan dengan tingkat dimana sejauh mana gaji memenuhi harapan-harapan pegawai, dan bagaimana gaji diberikan. (c) faktor kesempatan atau promosi, merupakan faktor yang berhubungan dengan kesempatan pegawai untuk mengembangkan diri dan memperluas pengalaman kerja, dengan terbukanya kesempatan untuk kenaikan jabatan. (d) faktor supervisor, merupakan faktor yang berhubungan dengan kemampuan supervisor untuk menyediakan bantuan teknis dan perilaku dukungan. (e) faktor rekan kerja, merupakan faktor yang berhubungan dengan kebutuhan dasar manusia untuk melakukan hubungan sosial; akan terpenuhi dengan adanya rekan kerja yang mendukung pegawai.

\section{Pengaruh Motivasi Kerja Terhadap Kepuasan kerja}

Dari data di atas, motivasi kerja berpengaruh positif terhadap kepuasan kerja pegawai. Hal ini menunjukkan bahwa semakin tinggi motivasi kerja yang dirasakan oleh pegawai, maka kepuasan dan kinerja pegawai akan meningkat atau sebaliknya, semakin rendah motivasi kerja maka semakin rendah kepuasan dan kinerja pegawai. Motivasi kerja yang dimiliki oleh seorang pegawai melalui tingkat kegigihan akan membangkitkan semangat kerja yang ada dalam dirinya. Dengan motivasi kerja yang tinggi tersebut pegawai akan mencurahkan kemampuannya untuk kantor, dengan begitu tujuan dari kantor akan tercapai. Di bantu dengan rasa kepuasan kerja yang dimiliki oleh pegawai dapat membuat pegawai selalu berpikir positif dan bekerja secara positif untuk melakukan hal-hal lain selain pekerjaannya. Kedua hal ini sangat baik bagi LPKA Klas IIA Ambon, karena pegawai yang termotivasi dan puas mampu bekerja dengan baik secara formal (in-role) atau pun informal (extra-role). Antonio dan Sutanto (2014) menyampaikan hal senada, intansi yang sukses memerlukan pegawai yang mampu dan mau mengerjakan tugas yang bukan termasuk tugas formal mereka. 


\section{Pengaruh Motivasi Kerja Terhadap Kepuasan kerja Dalam Perspektif Kristiani}

Bagaimana pemahaman yang seutuhnya dari Firman Tuhan?, Pekerjaan bukanlah kutuk seperti pandangan sebahagian orang yang mengutip Alkitab dimana Allah memberikan hukuman atas dosa Adam dan Hawa, "Terkutuklah tanah karena engkau, dengan bersusah payah engkau akan mencari rezekimu dari tanah seumur hidup mu" (baca Kej 3:17). Kalau kita perhatikan dengan cermat, Allah memang mengutuk tanah, sehingga menghasilkan semak duri dan rumput duri, namun pekerjaan itu sendiri bukanlah kutuk, karena perintah untuk bekerja sudah diberikan Allah sebelum manusia itu jatuh ke dalam dosa (baca $\quad$ Kej $1: 28 ; \quad 2: 15$ ).

Bekerja adalah merupakan gambaran Allah kita yang adalah bekerja (baca, Kej 2:2, "Ketika Allah pada hari yang ketujuh telah menyelesaikan pekerjaan yang dibuat-Nya itu....."), Bahkan hingga saat ini Allah terus bekerja (band. Yoh 5:17 " Tetapi Ia berkata kepada mereka: "Bapa$\mathrm{Ku}$ bekerja sampai sekarang, maka Aku pun bekerja juga") dan pekerjaan Allah itu dinyatakan sebagai menegakkan ciptaannya (Kol 1:16); memenuhi segala kebutuhan dari ciptaan-Nya (Mzm 104:10-30) dan menyelesaikan pekerjaan penebusan (Yoh 4:34). Bahkan yang lebih menarik adalah bahwa Allah menciptakan manusia sebagai rekan kerjaNya (lihat kembali, kej 2:8,15). Maka perlu kita pahami bahwa bekerja bukanlah hanya untuk menghasilkan sesuatu, tetapi sebagai karakter Allah itu sendiri yang diberikan juga kepada manusia Selain nilai intrinsik, maka pekerjaan yang Allah berikan juga memiliki nilai instrumental, dimana melalui pekerjaan kita dapat melayani orang lain, memenuhi kebutuhan hidup dan keluarga dan melalui pekerjaan kita mengasihi Allah.

Oleh karena itu dengan pandangan yang benar terhadap pekerjaan kita akan diarahkan untuk melakukan yang terbaik dalam pekerjaan dan pelayanan kita, dengan tidak perlu membandingkan apakah pekerjaan/ pelayanan kita lebih baik atau tidak dari orang lain, karena Allah yang akan mengujinya (baca, 1 Kor 3:13-15, Sekali kelak pekerjaan masingmasing orang akan Nampak. Jika kita memiliki pandangan dan dasar yang benar akan pekerjaan maka kita akan memiliki etos kerja yang baik.

\section{KESIMPULAN}

1. Motivasi kerja oleh karyawan berpengaruh terhadap kinerja. Semakin tinggi kepuasan kerja yang dirasakan oleh karyawan, maka kinerja karyawan akan meningkat.

2. Iman Kristen mengenai kerja mempengaruhi motivasi kerja yang dialami oleh karyawan yang tentunya akan berpengaruh terhadap kinerja. Semakin tinggi kepuasan kerja yang dirasakan oleh karyawan, maka kinerja karyawan akan meningkat. Allah dalam Yesus Kristus akan dimuliakan melalui pekerjaan dan pengabdian para karyawan.

\section{DAFTAR PUSTAKA}

Abineno J.L. 2006. Apa Kata Alkitab. Jakarta: BPK Gunung Mulia.

Dewi Ma'rifah. 2006. Pengaruh Motivasi Kerja dan Budaya Organisasi Terhadap Kinerja Pekerja Sosial pada Unit Pelaksana Teknis Dinas Sosial Propinsi Jawa Timur. http://www.damandiri.or.id. Diakses Tanggal 1 Maret 2010.

Edhi Prasetyo et al. 2003. Pengaruh Motivasi dan Kepuasan Kerja Terhadap Produktivitas Kerja Karyawan Riyadi Palace Hotel di Surakarta. Program Pascasarjana Universitas Muhammadiyah Surakarta. Solo.

Douglas J.D. 2002. Ensiklopedi Alkitab Masa Kini Jilid I (A-L). Jakarta: Yayasan Komunikasi Bina Kasih/OMF.

O'Collins et al. 2004. Kamus Teologi. Yogyakarta: Kanisius.

Sutarto Wijono, Psikologi Industri Dan Organisasi Dalam Suatu Bidang Gerak Psikologi Sumber Daya Manusia Edisi Revisi. Jakarta: Kencana 2014

Sugiono, 2012. Metode Penelitian Kualitatif dan Kuantitatif. Jakarta: Alfabeta.

Lembaga Alkitab Indonesia, 2000. Tafsiran Alkitab Masa Kini. Jakarta: BPK Gunung Mulia.

Verkuyl J. 2003. Aku Percaya. Jakarta: BPK Gunung Mulia. 